\title{
A Journey into the Interior of Ashanti
}

\section{Author(s): Brandon Kirby}

Source: Proceedings of the Royal Geographical Society and Monthly Record of Geography, Vol. 6, No. 8 (Aug., 1884), pp. 447-452

Published by: Wiley on behalf of The Royal Geographical Society (with the Institute of British Geographers)

Stable URL: http://www.jstor.org/stable/1800724

Accessed: 27-06-2016 02:34 UTC

\section{Your use of the JSTOR archive indicates your acceptance of the Terms \& Conditions of Use, available at}

http://about.jstor.org/terms

JSTOR is a not-for-profit service that helps scholars, researchers, and students discover, use, and build upon a wide range of content in a trusted digital archive. We use information technology and tools to increase productivity and facilitate new forms of scholarship. For more information about JSTOR, please contact support@jstor.org.

The Royal Geographical Society (with the Institute of British Geographers), Wiley are collaborating with JSTOR to digitize, preserve and extend access to Proceedings of the Royal Geographical Society and Monthly Record of Geography 
them to understand what they saw, and to bring back an account of what they had done which would really add to the stock of valuable knowledge which the world possessed with regard to those mountains.

Mr. Graham said the bearing of the high peaks which he saw was almost due north-west, with a trifle west. When he got down he had his instruments compared, and they were fairly accurate. Many of the heights were well known, and the aneroid barometer might be fairly reckoned on for differential measurements.

Mr. Freshrield observed that in one of the surveys published by the Indian Survey Department two peaks with an indication "Very high snowy peaks," were put down on the authority of one of the native surveyors or pundits, "No. 9," to the north-west of Kabru, north of the Arun river, and north-east of Mount Everest, on the real water-parting of the Himálayas.

General WALKER replied that the bearing of those peaks was no doubt all right, but the native explorers had no means of estimating the altitude, which might be anything between 20,000 feet and 30,000 feet.

The President, in proposing a vote of thanks to Mr. Graham, said that gentleman had taken them to one of the most magnificent regions in the world, and considering that he went to India more for sport and adventure than for the advancement of science, he had shown that he was a discoverer of more than ordinary intelligence. If he returned to those regions he would do so still better, supplied with the lamp of science to which General Strachey had referred. It was interesting to note how surveyors and discoverers had discrowned one peak after another from being the highest in the world. In his youth Dhawalagiri was considered to have dethroned the Andes; soon after Kangchinjanga was discovered to overtop Dhawalagiri; then came a great surveyor who dethroned Kangchinjanga in favour of the mountain which now bore the name of Mount Everest; and now, if $\mathrm{Mr}$. Graham was right, and there appeared to be no reason to doubt it, Mount Everest must bow its cloud-capped head. No doubt others would be stirred to rival $\mathrm{Mr}$. Graham, and very soon the mystery would be solved. At any rate, Mr. Graham had made a very interesting addition to the knowledge of this stupendous region, and it must be very gratifying to men like Sir Joseph Hooker, who led the way there, to find that they were followed by youthful adventurers like Mr. Graham.

\section{A Journey into the Interior of Ashanti. By Captain Brandon Kirby.}

(Read at the Evening Meeting, June 23rd, 1884.)

Map, p. 488.

The following is a brief account of a journey $I$ have recently made to the northern limits of what was formerly the Ashanti kingdom. Although many white people have visited Coomassie and the country to the east and west of it, I believe I am the first white man who has penetrated the country due north of Coomassie through Coranza, and who has reached in that district the southern limits of those inland nations who had hitherto been prevented from communication with the seaboard by the formerly impassable barrier of Ashanti power.

I may state that my first introduction to West Africa was in 1881, 
when, hearing of a threatened Ashanti war, I volunteered at a very short notice for the Gold Coast Constabulary and proceeded to Elmina on the staff of H.E. Sir Samuel Rowe.

We landed at Elmina on the 4th of March, 1881, and in a short time after the whole of the Ashanti difficulty was overcome. The golden axe, an emblem of war, which had previously been sent to the coast with a very warlike message, had, together with about $6000 l$. in gold, been sent home accompanied by an apology from the King of Ashanti. Six weeks after landing I found myself one of the few remaining members of His Excellency's staff; the others having all returned directly the difficulties had been settled. After this I visited nearly all the country within the protectorate, proceeding from Prahsue, which marks the limit of the protectorate, to Accra, via Assin and Eastern and Western Akim. I afterwards visited the Volta district and Lagos, proceeding home on leave in May 1882. I returned to the West Coast again in December of the same year, and in the April of 1883 I accompanied Captain Barrow on his mission to Coomassie, living in and around that city for nearly five weeks. During this time I visited the ex-King Coffee Kalkali; King Coffee informed me that although he had had white men prisoners and had fought white soldiers, I was the first white he had conversed with. In the commencement of 1884 I started, by command of Sir Samuel Rowe, on another journey to the Ashanti kingdom, and it was whilst performing this mission that I succeeded in pushing my way to its extreme northern limits. During the short time I had been in West Africa, the Ashanti kingdom had undergone some very considerable changes, and in 1883, instead of a golden axe being sent to the Governor, it was a message begging of His Excellency to assist in quelling a civil war that was then proceeding in Ashanti, and asking the Governor to give his judgment in favour of either of the rival candidates.

The Ashanti chiefs begged Sir Samuel to hold a durbar at Prahsue and hear the rival claims, and it was part of my mission to visit all the chief towns of Ashanti and gather what information I could for the use of the Governor.

Since the intervention of His Excellency towards peace, Coomassie shows signs of again returning partly to its old prosperity. The streets and chief palaces, which suffered during the recent civil war, are being rapidly rebuilt, but I do not think that Ashanti as a power will regain its old strength over the neighbouring tribes, although for a distance of about 50 miles round Coomassie the Ashanti King's word will be law ; I was informed by Quaco Duah, the new King, that, acting on the advice of the British Governor and also the wish of the white Queen, he had stopped all human sacrifices. This was fully borne out by the non-existence of any carrion birds round Coomassie and its suburbs. On my previous visit to Coomassie the place was literally swarming with these birds. 
Gold is still found in small quantities in the streets of Coomassie, but, being surface gold, it is worked only during the rainy season. All gold found in Coomassie pays a duty of 50 per cent. The gold taken in duty is given to the royal goldsmith to be worked up in the regalia of the country. Gold ornaments, \&c., are all cast, a wax model being first made and then cast from clay. Gold-mining in Ashanti may be said to be entirely confined to the provinces of Dadiassie and Inquanta, and the seam of gold which runs through them appears to be a continuation of the seam that starts near Kibbi, Eastern Akim, and proceeds in a westerly direction through Western Akim, entering Ashanti near Amantia, at which place in Ashanti gold-mining first commences. This seam then passes through Dadiassie and proceeding through a portion of the Adansi country near Fomenah, the capital, strikes south and thence through Inquanta, and so on into the Tarquah country, which is again within the protectorate.

In Bowditch's work on Ashanti, mention is made of the King and chiefs wearing leather boots and dresses. Although I myself, during my visits to Coomassie, have never seen any of these things, Bowditch's description quite tallies with the leather goods offered for sale in Quantampoh. In old days Coomassie being able to command all the roads to the interior, she was always in a position to procure an abundant supply of these articles.

Amongst the new branches of commerce starting in Ashanti is the indiarubber trade. The forest from Adansi to Coomassie, and so on in a north-east direction to Mampong, is very full of the indiarubber vine. At present all this industry is in the hands of natives from the protectorate.

Some 80 to 100 miles north of Coomassie, the first open country is struck. By this I mean that the dense jungle which commences near the sea-coast, and continues 100 miles west of Coomassie, is passed, and one enters a country with very long grass and a few stunted trees at irregular distances apart, closely resembling an apple orchard in winter. During my journey north these trees had quite a blighted appearance; none of them having any leaves on them, and the stems being very much scorched from the continual burning of the grass round them. But on my return journey in a few weeks, they had all started into leaf again. On leaving the dense bush the soil immediately becomes sandy, and all mud houses cease; the house of the native being the circular grass hut with a hole through which to crawl in, and in shape like a beehive.

Quantampoh is situated north-east of Coomassie about 80 miles. It is built in the midst of a large sandy plain, every particle of wood having been cleared away for some miles round. The resident population of Quantampoh is about 15,000, and the traders passing through would be about 25,000, making altogether a population of 40,000 . Quantampoh was in old days one of the principal, if not the principal, ivory markets for this part of Africa, but owing to the continual wars 
in Ashanti and its borders, and also the blocked state of the roads leading to the seaboard, combined with the heavy duties imposed on all goods passing through Ashanti, the ivory trade was driven away.

During the time I was in Quantampoh, caravans arrived from Timbuctu viâ the Moshi country and also Mandingos from the back of Sierra Leone. They brought articles of European manufacture, viz. cotton goods, knives, and thread. Caravans take great quantities of the kola nut from Quantampoh.

The only edifices built of mud are the mosques and the houses of the principal chiefs. The mud for building these is brought from some distance. In journeying from Coomassie to Quantampoh three small streams only are passed. They all run in an easterly direction, and none of them are more than four feet deep.

Prayers are offered twice each day in Quantampoh. Shortly after morning prayer the slaughtering for that day's meat consumption takes place. The cattle in this part of the country closely resemble those seen at the Gambia and Sierra Leone, having the hump on their backs, but they are larger than at either of those places, and are not confined to any one colour, like those brought from the Soo-Soo country. Coranza is the last place in which you are able to make any use of English money, and at this place the rate of exchange is very heavy. You get only about $12 s$. $6 d$. for $1 l$. sterling. Cowries now are the only currency. The principal merchandise offered in the market for sale came from France through the Gaman country.

During my stay in Quantampoh I was made aware of the fact that this market is much resorted to for the purchase of slaves. Although, during the time I remained in the town, I saw no slaves openly offered for sale, yet I sometimes accidently intruded into the yards of some of the principal chiefs, and there found numbers of slaves, both male and female, chained together in batches of about a dozen, and awaiting purchasers. These people come from the east of Quantampoh and from the countries much farther in the interior. They are principally purchased by the caravans going north. The average price of a strong and healthy slave is from $2 l$. to $3 l$.

On one occasion, walking through the town at daybreak, I came on a gang of these slaves who were being marched off. They were in single file, following each other according to African custom. They were chained together; each one was carrying a load, and, apparently surprised at seeing me, they were hurried off as quickly as could be.

After the paper,

Sir SAMUEL Rowe said that an important part of his duties on the Gold Coast was to try to keep peace among the natives and promote trade. Formerly the Ashanti power overlapped the British possessions on either side, and stretching far into the interior, received tribute from places 200 miles beyond the borders of the Ashanti country. Access to the interior from the Gold Coast was barred by 
Ashanti, which compelled all trade from the surrounding neighbourhood to go to Coomassie. So long as they had the power, the Ashantis allowed no native or European to pass from the coast to the north through Coomassie, nor from the north through Coomassie to the sea-coast. It was evident, therefore, that if the trade of the colony was to prosper and peace was to be secured it was necessary to find some means of rendering the colony independent of Ashanti. When he was Governor of the West Africa Settlements, his efforts had been directed towards inducing the people from the inland territories to bring their caravans down to Freetown. In this he had been so far successful that caravans had come to Freetown from Dingarawa and Balia and Segu and Bamaku. The British authority at Sierra Leone went but a short distance inland; but the French posts on the Senegal had been pushed on towards the interior until they now approached the navigable part of the northern course of the Niger. After the expedition of Lord Wolseley, Dr. Gouldsbury, in 1876, under the Government of Sir George Strahan, had travelled through Coomassie to Salagha, and since he (Sir S. Rowe) first assumed the government of the colony in 1881, he had persevered in the policy of attempting to establish communications with the interior districts which lay beyond Ashanti. Captain Lonsdale in 1881 and 1882 had gone as far as Yendi on the north-east and Buntaku on the north-west, and Captain Kirby had lately been allowed to pass through Coomassie to the very northern limit of Ashanti, where at Kontampo (Quantampoh), on the extreme confines of the Coranza district, he had met with a detachment from the caravan which comes down south on the one side from Timbuctu and on the other from Sakatu (Sokotoo). It had been long known that such caravans passed east and west along the northern boundaries of Ashanti. From Sakatu, the caravans pass on by Lake Chad to the eastward. Along this caravan route there is a constant stream of travel, Mahommedan pilgrims passing in some numbers to Mecca. He knew of at least two caravans that travel every year on the westward route between Morocco and Timbuctu. The fact that Captain Kirby met with European goods in the stores of the caravan which came to Kontampo (Quantampoh) from the north, showed that if free access were obtained from the coast to these trading caravans, a considerable business could be carried on. He thought that communication between the sea-coast of the colony and these interior trading routes should be encouraged. He was sure the result would be of advantage to British trade.

The President, in proposing a vote of thanks to Captain Kirby, said he was glad to hear that good results had followed the expedition to Ashanti, for it was not always that invasions of barbarous countries produced good effects. It appeared to him that the diminution of the Ashanti power was a beneficial thing, for that power was a cruel and barbarous one, and the fact mentioned by Captain Kirby that English influence had put an end to the wholesale sacrifice of human beings was sufficient to repay this country for the cost of the Ashanti expedition. He considered it impossible that English commerce would allow goods to be brought overland from Morocco or Tripoli through the desert when they might easily be conveyed from the Gold Coast to the interior if a secure route was obtained. The two towns of Kano and Yoruba had been called the Manchesters of Africa. They were towns of 30,000 and 150,000 inhabitants, and caravans from all parts met there, so that great exchanges took place, and all the materials existed for an extensive trade. No doubt, as peace was established and our knowledge of those countries increased, the sort of trade which led to civilisation would extend.

The President, in conclusion, said that with this meeting the session for 1883-4 terminated. He wished to add that Mr. Thomson was on his way to England, and that it had been hoped he would be home in time for the Society to hold a supple- 
mentary meeting in order to listen to his account of his travels; but as he had to make his way from Zanzibar to Bombay, and thence to this country, he could hardly be expected to arrive at a sufficiently early date. He was, however, sure that the Society would meet in large numbers to welcome him at the opening of the session in November next.

\title{
Explorations in the Neighbourhood of Mounts Roraima and Kukenam, in British Guiana.
}

\section{By Henry Whitely.}

\author{
Map, p. 488.
}

Mr journeys to the extraordinary table-topped mountains, Roraima and Kukenam, in the interior of British Guiana, were undertaken in the course of the natural history explorations of the interior in which $I$ have been engaged during the last five years. I had previously spent twelve years in the same pursuit in the province of Paucartambo, province of Cuzco, in Southern Peru, and returning to England, arranged in 1879 to visit British Guiana, with the object of making as perfect a collection as possible of the birds and insects of that interesting country. My instructions were to leave the coast and get into the forest country below the rapids, making my headquarters either at Bartica Grove Mission, on the Essequibo river, or in the vicinity of the penal settlement on the Mazaruni. These I carried out by taking up my residence at Bartica Grove, and here and in the surrounding district I was occupied up to February 1881, by which time I had succeeded in obtaining 200 species of birds.

The following is a brief account of my various excursions in the far interior :-

Having purchased stores and engaged boat hands, I left the Grove in March 1881, and reached Camacusa, a place on the Mazaruni just above the mouth of the Merumé river, in the same month. I collected in this locality till April 24th, 1881, obtaining many interesting birds, not found at Bartica Grove. Leaving Camacusa on April 27th, 1881, for a long journey beyond the Merumé Mountains, I travelled up the Merumé river, reaching the landing whence it was necessary to make the ascent, in the afternoon of April 30th. Unfortunately it rained heavily on the mountains that night, and the river came down in a tremendous volume in the early morning of May 1st, nearly spoiling all my provisions, and filling my tin boxes. This accident delayed me two days.

After my ascent of the mountain, and arrival on the other side of the Upper Mazaruni just above Chichi great falls, I met with a serious accident, which nearly put an end to my explorations. Having opened some of my powder-flasks and found the powder wet, I foolishly set to 


\section{A S HAN T I}

to illustrate Capt. Brandon Kirby's journey into the Interior; with additions from the Survey of Capt ${ }^{n}$ Lonsdale C.M.G. and Insp. C.W.'Thompson ER.G.S

$$
\begin{aligned}
& \text { Captn Kirby's route } \\
& \text { out }
\end{aligned}
$$

approx. former Boundary of Asharti King dom

"present $d: " d$ :

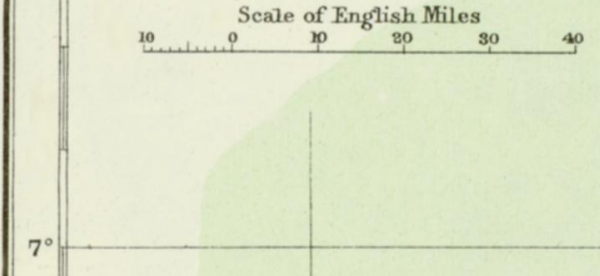$$
6^{\circ}
$$

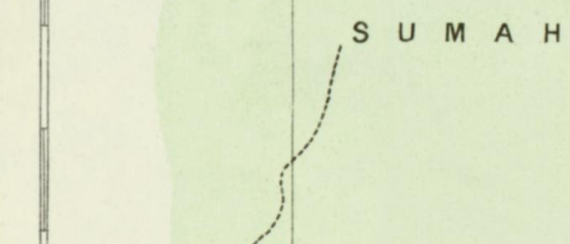

$6^{\circ}$
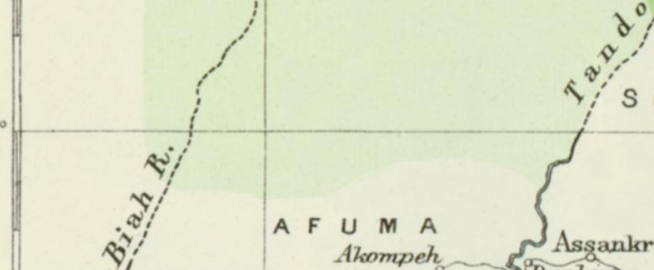

k:

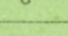

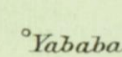

Bontuku。

- Kerabi

Kontosu ${ }^{\circ}$

-Nomasa

aAnkoma

-Takima

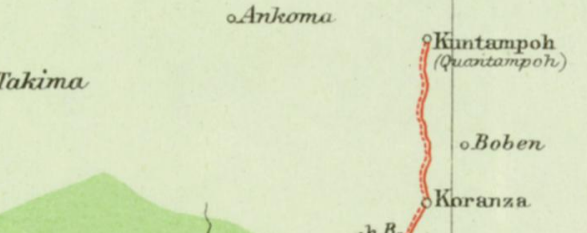

4: S E H W H I Denkera

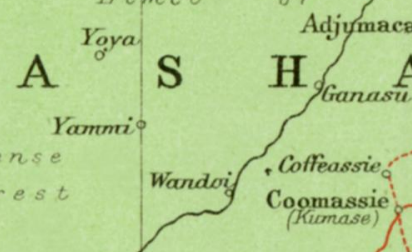




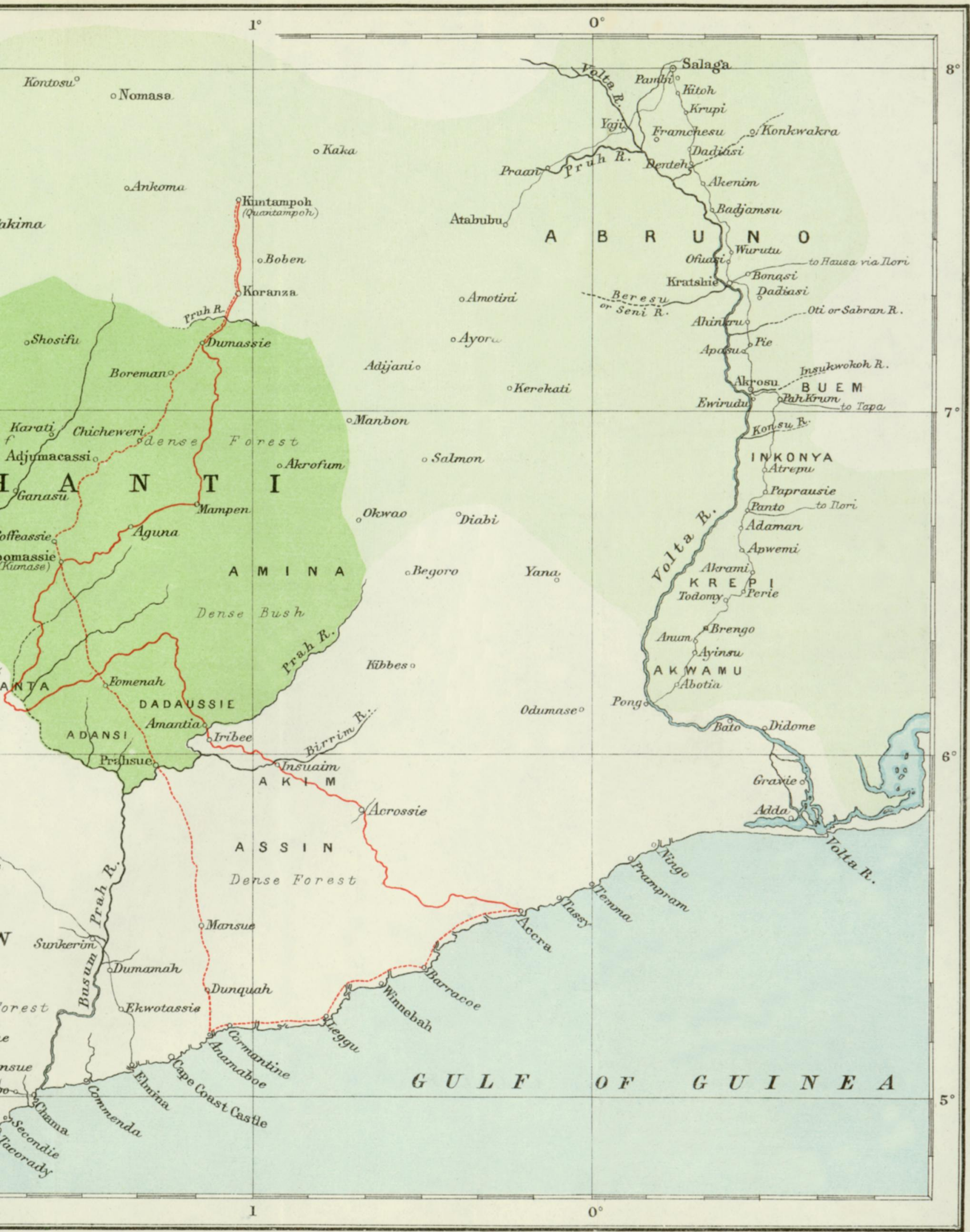

